Supporting information for:

\title{
Autoxidation of Limonene Emitted in a University Art Museum
}

Demetrios Pagonis $^{1,2}$, Lucas B. Algrim ${ }^{1,2}$, Derek J. Price ${ }^{1,2}$, Douglas A. Day ${ }^{1,2}$, Anne V. Handschy $^{1,2}$, Harald Stark ${ }^{1,2,3}$, Shelly L. Miller ${ }^{4}$, Joost de Gouw ${ }^{1,2}$, Jose L. Jimenez ${ }^{1,2}$, and Paul J. Ziemann ${ }^{1,2 *}$

${ }^{1}$ Cooperative Institute for Research in Environmental Sciences (CIRES), University of Colorado, Boulder, Colorado 80309

${ }^{2}$ Department of Chemistry, University of Colorado, Boulder, Colorado 80309

${ }^{3}$ Aerodyne Research, Inc., Billerica, Massachusetts 01821

${ }^{4}$ Department of Mechanical Engineering, University of Colorado, Boulder, Colorado 80309

*Corresponding email: paul.ziemann@colorado.edu 
Particulate matter density and limonene SOA molecular weight. The density of $1.5 \mathrm{~g}$ $\mathrm{cm}^{-3}$ used to calculate background aerosol mass concentrations from the scanning mobility particle sizer (SMPS) data was calculated using measurements of ambient aerosol taken in 2013 using an aerosol mass spectrometer. ${ }^{1}$ These measurements were conducted from a laboratory 200 $\mathrm{m}$ from the University of Colorado Art Museum, and the density was calculated from the aerosol chemical composition using the approach presented in Hu et al. ${ }^{1}$ and DeCarlo et al. ${ }^{2}$. The density and molecular weight of limonene ozonolysis SOA were estimated to be $1.5 \mathrm{~g} \mathrm{~cm}^{-3}$ and $255 \mathrm{~g}$ $\mathrm{mol}^{-1}$, respectively - the same as those reported for $\alpha$-pinene autoxidation SOA at $65 \%$ RH by Claflin et al. ${ }^{3}$. The density and molecular weight of SOA formed from reaction of limonene with $\mathrm{NO}_{3}$ were estimated to be $1.2 \mathrm{~g} \mathrm{~cm}^{-3}$ and $203 \mathrm{~g} \mathrm{~mol}^{-1}$, respectively - the same as those reported by Claflin ${ }^{4}$. The aerosol mass concentration (Figure 3 of the text) is calculated from the SMPS aerosol volume measurement using the densities presented above, by assuming that the background aerosol is constant, and by assuming that all of the increase in aerosol volume above the background is attributable to SOA formed from limonene- $\mathrm{O}_{3}$ and limonene- $\mathrm{NO}_{3}$ reactions. 


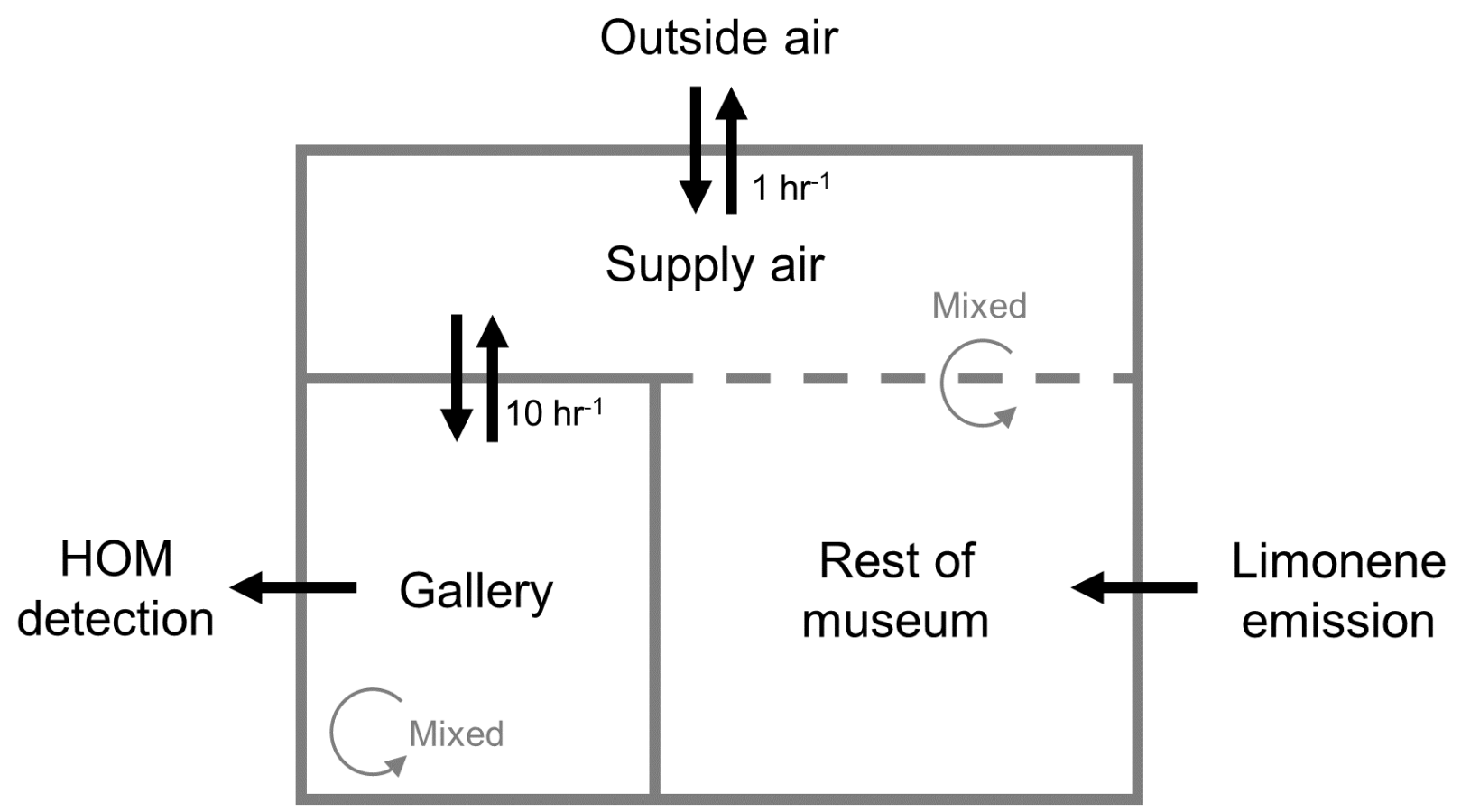

Figure S1. Schematic of the box model used to describe transport, partitioning, and chemistry inside the University of Colorado Art Museum. ${ }^{5}$ The two compartments, gallery and supply air + rest of the museum are each assumed to be well mixed. HOMs were sampled from gallery air and all other trace gases were sampled from both the gallery air and supply air. The supply air measurement occurs downstream of all conditioning, allowing time for the air recirculated from the different rooms within the rest of the museum to mix.

Relative contribution of $\mathrm{O}_{3}, \mathrm{NO}_{3}$, and $\mathrm{OH}$ to $\mathrm{HOM}$ formation. Following the emission of limonene in the University of Colorado Art Museum the concentration of HOMs detected by the $\mathrm{NO}_{3}$-CIMS increased. Formation of HOMs via limonene ozonolysis have been documented previously, and here we use our chemical box model of the museum to explore whether there is any evidence of HOMs formed from $\mathrm{NO}_{3}$-initiated autoxidation of limonene. To calculate the relative contributions of limonene- $\mathrm{O}_{3}$ oxidation products ([Prod] $]_{03}$ ) and limonene$\mathrm{NO}_{3}$ oxidation products $\left([\mathrm{Prod}]_{N O 3}\right)$ to the total HOM concentration $([\mathrm{HOM}])$ we first generate model estimates of [Prod $]_{\mathrm{O} 3}$ and $[\mathrm{Prod}]_{\mathrm{NO} 3}$ that assume a yield of 1 . We then express the $[\mathrm{HOM}]$ time series as a linear combination of those two product time series, as in Equation S1: 


$$
[\mathrm{HOM}]=Y_{\mathrm{O} 3}[\mathrm{Prod}]_{\mathrm{O} 3}+Y_{\mathrm{NO} 3}[\mathrm{Prod}]_{\mathrm{NO} 3}
$$

where $Y_{O 3}$ and $Y_{\mathrm{NO} 3}$ are the $\mathrm{HOM}$ yields of the limonene- $\mathrm{O}_{3}$ and limonene- $\mathrm{NO}_{3}$ reactions. Using Equation S1, we estimate $Y_{O 3}=0.1115 \pm 0.0007$ and $Y_{N O 3}=0.0018 \pm 0.0006$, respectively. The uncertainty listed is the fit uncertainty calculated by the Monte Carlo procedure described below and does not account for uncertainty in the model outputs. From these fit uncertainties we estimate that limonene- $\mathrm{NO}_{3}$ chemistry contributes between $0-4 \%$ of the total detected HOMs. Thus, $\geq 96 \%$ of the HOM signal is attributed to limonene- $\mathrm{O}_{3}$ oxidation products. The time series of limonene, $\mathrm{O}_{3}, \mathrm{NO}_{3}$, and two example HOMs are shown in Figure $\mathrm{S} 2$ and are overlaid with the model estimates of products of limonene- $\mathrm{O}_{3}$ and limonene- $\mathrm{NO}_{3}$ reactions. Included in Figure $\mathrm{S} 2 \mathrm{~A}$ is the model estimate of $\mathrm{NO}_{3}$ when the limonene emission event is not included, showing the impact of limonene on the modeled $\mathrm{NO}_{3}$ time series. The time series of $\mathrm{C}_{10} \mathrm{H}_{14} \mathrm{O}_{10} \cdot \mathrm{NO}_{3}{ }_{3}^{-}$presented in Figure $\mathrm{S} 2$ is the only $\mathrm{HOM}$ observed that shows a clear correlation to the model output of limonene- $\mathrm{NO}_{3}$ reaction products. For this reason, and because there is no clear mechanistic explanation for how $\mathrm{C}_{10} \mathrm{H}_{14} \mathrm{O}_{10}$ might be formed from a limonene- $\mathrm{NO}_{3}$ reaction, and the modeled $\mathrm{NO}_{3} \mathrm{HOM}$ yield is essentially zero once additional uncertainties from the model are included we cannot conclude that we detected any $\mathrm{HOMs}$ from $\mathrm{NO}_{3}$-initiated autoxidation.

Because the only source of $\mathrm{OH}$ radicals in the museum is alkene ozonolysis, and the only VOC in the model is limonene, the model estimates of limonene-OH reaction products are correlated with the estimates of limonene- $\mathrm{O}_{3}$ reaction products. Additionally, $\mathrm{HOM}$ yields from reaction of limonene-OH reactions have not been studied to our knowledge. Because of these limitations, we do not attempt to separate $\mathrm{HOM}$ formation from limonene- $\mathrm{OH}$ and limonene- $\mathrm{O}_{3}$ 
reaction pathways, instead treating them as a single pathway described by the limonene- $\mathrm{O}_{3}$ reaction rate.
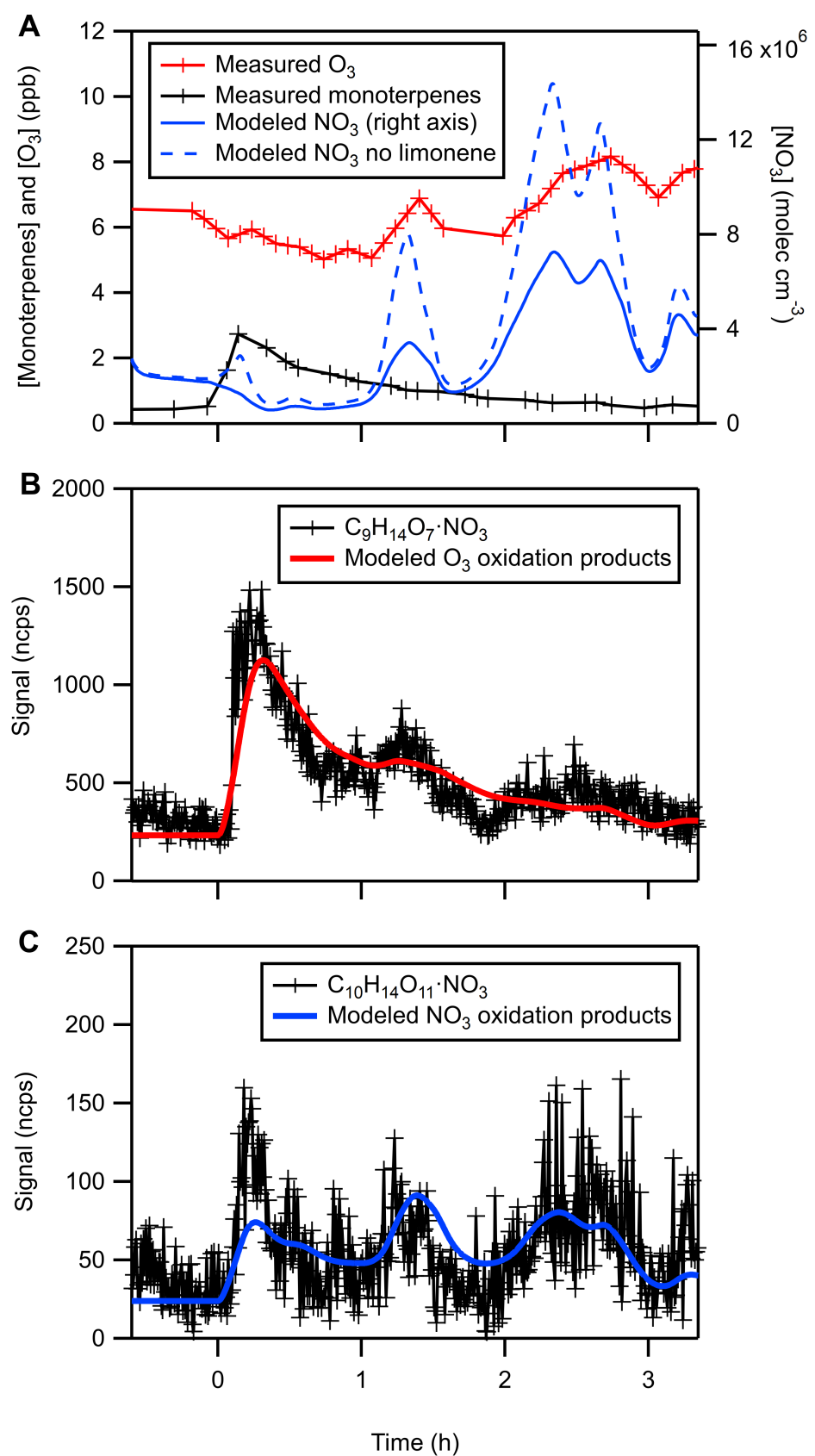

Figure S2. (A) Time series of measured $\mathrm{O}_{3}$, measured monoterpenes, modeled $\mathrm{NO}_{3}$ during the limonene emission event, and modeled $\mathrm{NO}_{3}$ when the limonene emission event is excluded. (B) Measured HOM time series that correlates with model estimates of $\mathrm{O}_{3}$ oxidation products and (C) $\mathrm{NO}_{3}$ oxidation products. Model outputs in panels $\mathrm{B}$ and $\mathrm{C}$ have been scaled to facilitate comparison with $\mathrm{NO}_{3}$-CIMS data. 
Monte Carlo error analysis of fit parameters. To estimate the uncertainty in fit parameters in this study we conducted Monte Carlo error analysis (1,000 simulations). First, a best-fit solution was determined using model outputs and Equation S1. Then, for each simulation, the measurement error was applied to the best-fit solution to generate a new synthetic data set. New parameters were then fit to the synthetic data, generating 1,000 sets of model parameters. The uncertainty reported in the text is the standard deviation of the Monte Carlo parameters calculated against the best-fit parameters. These uncertainties only reflect the uncertainty introduced by the fitting procedure, and they do not reflect uncertainty in model estimates of $\mathrm{NO}_{3}$ and $\mathrm{O}_{3}$ reaction rates. 


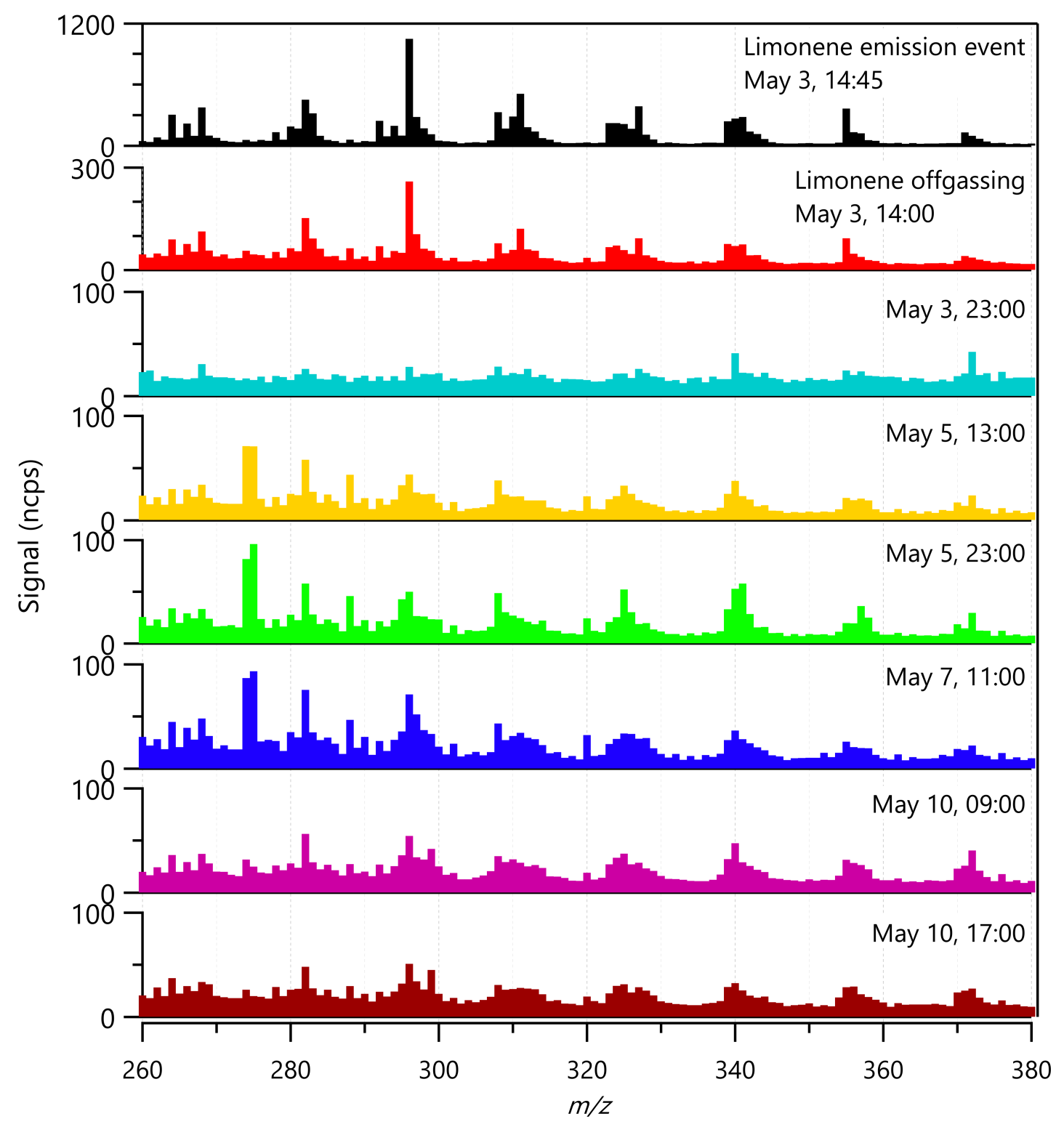

Figure S3. Comparison of $\mathrm{NO}_{3}$-CIMS mass spectra preceding and during the limonene emission event with mass spectra obtained at other times with no associated emission event. The spectra were chosen randomly from the complete data set and are 1-hour averages. The lower signal intensity and differing mass spectral patterns indicate that there is not a persistent limonene HOM background in the museum, and that the HOMs observed prior to the limonene emission event are likely due to limonene off-gassing from the orange prior to it being peeled. All spectra are normalized per million counts of reagent ion. 
Table S1. Detected ion $\mathrm{m} / \mathrm{z}$ values and assigned elemental formulas for HOMs formed from limonene ozonolysis in the museum and measured using $\mathrm{NO}_{3}-\mathrm{CIMS}$. Unassigned ions are not listed. $\mathrm{NO}_{3}$-CIMS detection of $\mathrm{RO}_{2}{ }^{\cdot}$ radicals has been documented for monoterpene autoxidation systems, ${ }^{6}$ and so not all assigned formulas correspond to closed-shell species. High-mass ions in the table that are above the mass range shown in Figure 1 of the text can be assigned to dialkylperoxide dimers formed by gas-phase reactions of $\mathrm{RO}_{2} \cdot$ radicals.

$\begin{array}{llll}\text { Assigned formula } & m / z & \text { Assigned formula } & m / z\end{array}$

\begin{tabular}{|c|c|c|c|}
\hline $\mathrm{C}_{9} \mathrm{H}_{14} \mathrm{O}_{5} \cdot \mathrm{NO}_{3}^{-}$ & 264.07249 & $\mathrm{C}_{10} \mathrm{H}_{16} \mathrm{O}_{8} \cdot \mathrm{NO}_{3}^{-}$ & 326.072884 \\
\hline $\mathrm{C}_{9} \mathrm{H}_{16} \mathrm{O}_{5} \cdot \mathrm{NO}_{3}^{-}$ & 266.08814 & $\mathrm{C}_{9} \mathrm{H}_{13} \mathrm{O}_{9} \cdot \mathrm{NO}_{3}^{-}$ & 327.044323 \\
\hline $\mathrm{C}_{9} \mathrm{H}_{16} \mathrm{O}_{6} \cdot \mathrm{NO}_{3}^{-}$ & 281.07523 & $\mathrm{C}_{9} \mathrm{H}_{16} \mathrm{NO}_{8} \cdot \mathrm{NO}_{3}^{-}$ & 328.075958 \\
\hline $\mathrm{C}_{7} \mathrm{H}_{11} \mathrm{NO}_{7} \cdot \mathrm{NO}_{3}^{-}$ & 283.041918 & $\mathrm{C}_{10} \mathrm{H}_{15} \mathrm{NO}_{8} \cdot \mathrm{NO}_{3}^{-}$ & 339.068133 \\
\hline $\mathrm{C}_{10} \mathrm{H}_{15} \mathrm{O}_{6} \cdot \mathrm{NO}_{3}^{-}$ & 293.07523 & $\mathrm{C}_{10} \mathrm{H}_{14} \mathrm{O}_{9} \cdot \mathrm{NO}_{3}^{-}$ & 340.052148 \\
\hline $\mathrm{C}_{9} \mathrm{H}_{14} \mathrm{O}_{7} \cdot \mathrm{NO}_{3}^{-}$ & 296.062319 & $\mathrm{C}_{9} \mathrm{H}_{14} \mathrm{NO}_{9} \cdot \mathrm{NO}_{3}^{-}$ & 342.055222 \\
\hline $\mathrm{C}_{9} \mathrm{H}_{15} \mathrm{O}_{7} \cdot \mathrm{NO}_{3}^{-}$ & 297.070144 & $\mathrm{C}_{9} \mathrm{H}_{15} \mathrm{NO}_{9} \cdot \mathrm{NO}_{3}^{-}$ & 343.063047 \\
\hline $\mathrm{C}_{9} \mathrm{H}_{16} \mathrm{O}_{7} \cdot \mathrm{NO}_{3}^{-}$ & 298.077969 & $\mathrm{C}_{10} \mathrm{H}_{15} \mathrm{NO}_{9} \cdot \mathrm{NO}_{3}^{-}$ & 355.063047 \\
\hline $\mathrm{C}_{10} \mathrm{H}_{14} \mathrm{O}_{7} \cdot \mathrm{NO}_{3}^{-}$ & 308.062319 & $\mathrm{C}_{9} \mathrm{H}_{12} \mathrm{NO}_{10} \cdot \mathrm{NO}_{3}^{-}$ & 356.034487 \\
\hline $\mathrm{C}_{10} \mathrm{H}_{15} \mathrm{O}_{7} \cdot \mathrm{NO}_{3}^{-}$ & 309.070144 & $\mathrm{C}_{10} \mathrm{H}_{15} \mathrm{O}_{10} \cdot \mathrm{NO}_{3}^{-}$ & 357.054888 \\
\hline $\mathrm{C}_{9} \mathrm{H}_{14} \mathrm{NO}_{7} \cdot \mathrm{NO}_{3}^{-}$ & 310.065393 & $\mathrm{C}_{10} \mathrm{H}_{14} \mathrm{O}_{11} \cdot \mathrm{NO}_{3}^{-}$ & 372.041978 \\
\hline $\mathrm{C}_{10} \mathrm{H}_{17} \mathrm{O}_{7} \cdot \mathrm{NO}_{3}^{-}$ & 311.085794 & $\mathrm{C}_{19} \mathrm{H}_{32} \mathrm{O}_{7} \cdot \mathrm{NO}_{3}^{-}$ & 434.20317 \\
\hline $\mathrm{C}_{9} \mathrm{H}_{14} \mathrm{O}_{8} \cdot \mathrm{NO}_{3}^{-}$ & 312.057234 & $\mathrm{C}_{19} \mathrm{H}_{30} \mathrm{O}_{12} \cdot \mathrm{NO}_{3}^{-}$ & 512.162093 \\
\hline $\mathrm{C}_{9} \mathrm{H}_{15} \mathrm{O}_{8} \cdot \mathrm{NO}_{3}^{-}$ & 313.065059 & $\mathrm{C}_{20} \mathrm{H}_{30} \mathrm{O}_{14} \cdot \mathrm{NO}_{3}^{-}$ & 556.151922 \\
\hline $\mathrm{C}_{10} \mathrm{H}_{14} \mathrm{O}_{8} \cdot \mathrm{NO}_{3}^{-}$ & 324.057234 & $\mathrm{C}_{20} \mathrm{H}_{30} \mathrm{O}_{16} \cdot \mathrm{NO}_{3}^{-}$ & 588.141751 \\
\hline $\mathrm{C}_{10} \mathrm{H}_{15} \mathrm{O}_{8} \cdot \mathrm{NO}_{3}^{-}$ & 325.065059 & $\mathrm{C}_{20} \mathrm{H}_{30} \mathrm{O}_{18} \cdot \mathrm{NO}_{3}^{-}$ & 620.131581 \\
\hline
\end{tabular}




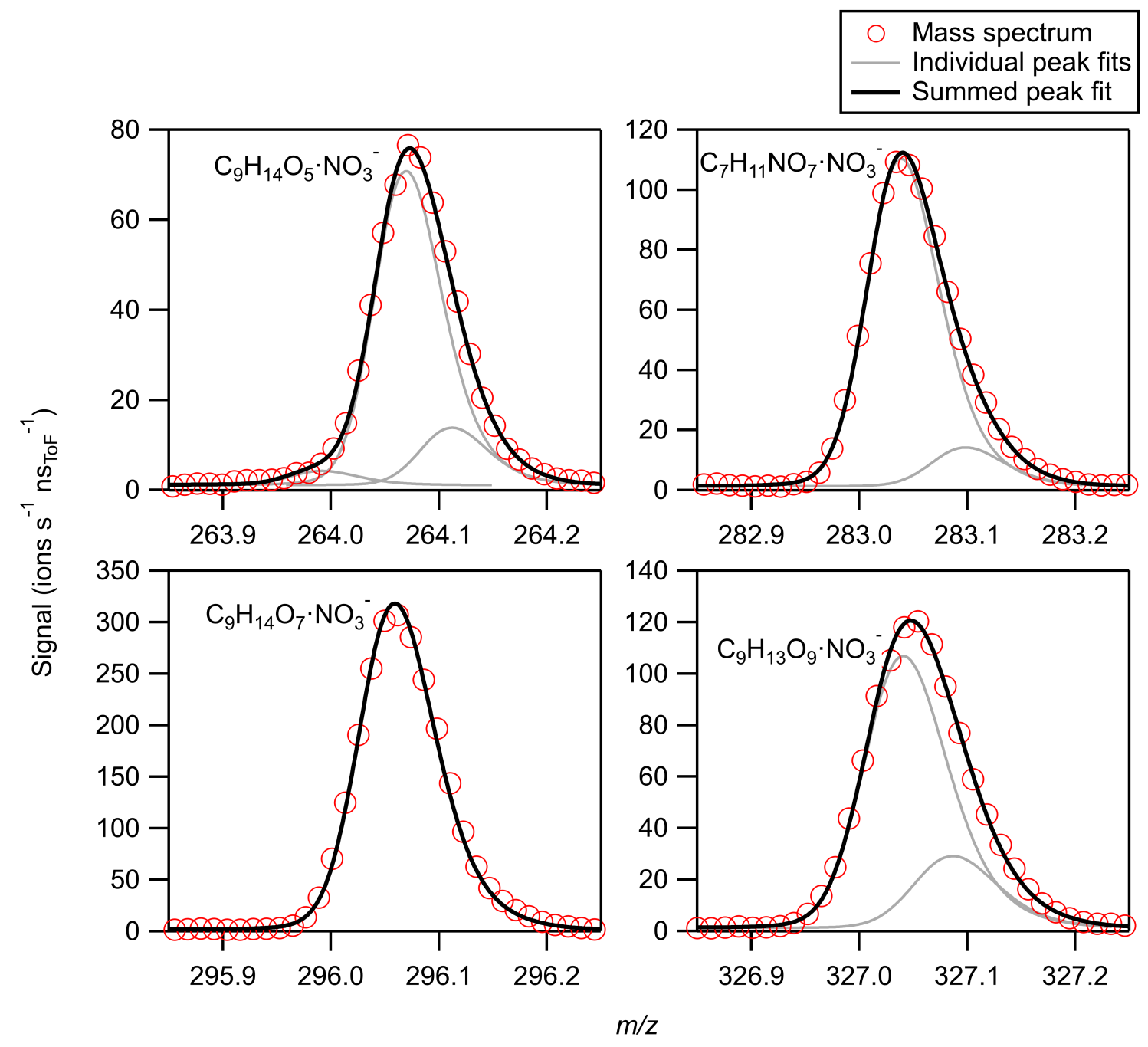

Figure S4. Example peak fits of identified HOMs detected by the nitrate-adduct high-resolution time-of-flight chemical ionization mass spectrometer. The mass spectrum is averaged over the hour following limonene emission and the assigned elemental composition of the highest intensity peak is included.

Condensational sink calculation. The aerosol condensational sink $k_{C S}$ for HOMs formed in the gallery was calculated to be $1.3 \times 10^{-3} \mathrm{~s}^{-1}$ using Equation $\mathrm{S} 2:^{7}$

$$
k_{C S}=\frac{1}{4} \gamma c S A
$$

Where the uptake coefficient $\gamma$ is assumed to be unity, the mean molecular speed is assumed to be $180 \mathrm{~m} \mathrm{~s}^{-1}$ (calculated assuming a molecular weight of $234 \mathrm{~g} \mathrm{~mol}^{-1}$ ) and the aerosol surface 
area concentration $S A$ of $28 \mu \mathrm{m}^{2} \mathrm{~cm}^{-3}$ is measured by the scanning mobility particle sizer. We do not include a transition regime correction because the surface area distribution measured by the SMPS peaks at a particle diameter of $65 \mathrm{~nm}$, where the correction is under $10 \%{ }^{7}$

Impact of aerosol filters on SOA yields. The SOA yields estimated in this study assume no effect of the museum's particle filters on the recirculation of aerosol within the building. The mode diameter of the size distribution measured during this period in the museum was $50 \mathrm{~nm}$, indicating that the MERV-8 and MERV-13 filters used in series in the museum's HVAC system were removing particles with diameters above $100 \mathrm{~nm}$ with high efficiency and that the filtration efficiency was lower for $50 \mathrm{~nm}$ particles. The mode diameter of the size distribution was unchanged following HOM formation. The efficiency of filters with a given MERV rating is variable, ${ }^{8}$ but one expects a MERV-13 filter to remove some fraction of particles with $D_{p}<100$ $\mathrm{nm}$. Accordingly, our assumption that the SOA formed from limonene emission was not removed by the building's filters likely underestimates the amount of SOA formed, and the SOA yields estimated above should be treated as lower bounds.

NO emissions by human breath. Taking the upper limit of the range of NO breath concentration of $50 \mathrm{ppb}$ reported by Travers et al. ${ }^{9}$ and a breath rate of $10 \mathrm{~L} \mathrm{~min}^{-1}$, we calculate an upper-limit NO emission rate of $30 \mu \mathrm{g}_{\text {person }}{ }^{-1} \mathrm{hr}^{-1}$. Using this emission factor and our calculated museum and gallery occupancies, we model the upper limit of NO concentration from human breath during the highest-occupancy period of the study: the 2017 Bachelor of Fine Arts Thesis Exhibit opening night, and the results are presented in Figure S5. During this event the museum averaged an occupancy of 176 people from 5:00-7:00 PM, local time. This level of occupancy brought the gallery $\mathrm{CO}_{2}$ concentration to $1,100 \mathrm{ppm}$, the maximum value observed during the campaign. The museum $\mathrm{O}_{3}$ concentration in the model output presented in Figure S5A 
is the average concentration during the opening ( $5 \mathrm{ppb}$ ). This is below the campaign average of $6.6 \mathrm{pb} \mathrm{O}_{3}$. When these conditions are used as inputs in the museum model (which includes reaction of $\mathrm{NO}$ with $\mathrm{O}_{3}$ ), the maximum concentration of $\mathrm{NO}$ emitted by human breath is modeled to be $0.41 \mathrm{ppb}$, corresponding to an estimated $\mathrm{RO}_{2}{ }^{\circ}$ radical lifetime of $10 \mathrm{~s}$. Since this lifetime is sufficiently slow to allow some autoxidation to proceed and the modeled NO emission rate is an upper limit, human $\mathrm{NO}$ emissions are not sufficient to change the oxidation regime of the museum's air without an additional source of $\mathrm{NO}_{\mathrm{x}}$ being present. The variation in $\mathrm{NO}$ concentrations caused by NO brought indoors from outdoor sources frequently exceeds the maximum possible contribution of occupants, as shown in Figure S5. If there were no $\mathrm{O}_{3}$ present inside the museum to titrate $\mathrm{NO}$ the model estimates a peak NO concentration during the opening of $1.4 \mathrm{ppb}$. This result indicates that occupants can change the oxidation regime of a building if the $\mathrm{O}_{3}$ concentrations and $\mathrm{NO}_{2}$ photolysis rates are sufficiently low.

The variability in the NO supply air time series is driven by strong, local sources of NO, which we attribute to local traffic and other combustion sources. The variability in outdoor NO is sufficiently fast that our 10-minute duty cycle switching between gallery air and supply air does not fully capture all the variability in the supply air concentration. This impacts the supply air:gallery NO concentration ratio when NO concentrations are $>2 \mathrm{ppb}$ in Figure S5. Because the residence time of the gallery is $6 \mathrm{~min}$, the fast variability in the supply air NO concentration is damped, and there is much less of a duty cycle artifact. 

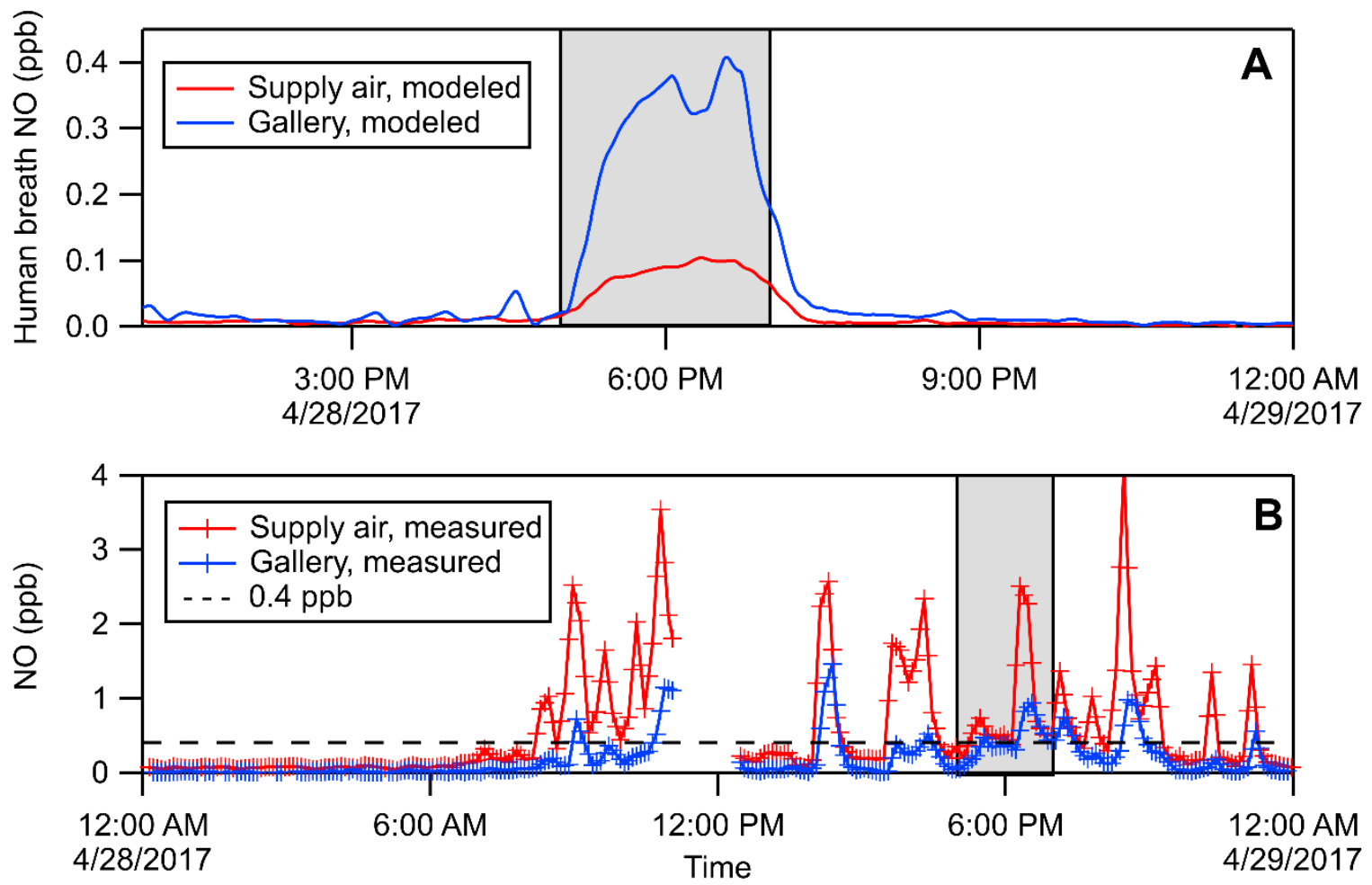

Figure S5. (A) Modeled upper limit of NO emitted in human breath in the museum, and (B) the measured NO time series for the day of the art exhibit opening. The hours of the opening are shaded in both panels. 


\section{References}

1. Hu, W.; Campuzano-Jost, P.; Day, D. A.; Croteau, P.; Canagaratna, M. R.; Jayne, J. T.; Worsnop, D. R.; and Jimenez, J. L. Evaluation of the new capture vaporizer for aerosol mass sectrometers (AMS) through field studies of inorganic species. Aer. Sci. Technol. 2017, 51, 735-754.

2. DeCarlo, P. F.; Slowik, J. G.; Worsnop, D. R.; Davidovits, P.; and Jimenez, J. L. Particle morphology and density characterization by combined mobility and aerodynamic diameter measurements. Part 1: Theory. Aerosol. Sci. Technol. 2004, 38, 1185-1205.

3. Claflin, M. S.; Krechmer, J. E.; Hu, W.; Jimenez, J. L.; and Ziemann, P. J. Functional group composition from ozonolysis of $\alpha$-pinene under high VOC and autoxidation conditions. ACS Earth Space Chem. 2018, 2, 1196-1210.

4. Claflin, M. S. Role of multiphase chemistry on the formation of aerosol from the reactions of monoterpenes with $\mathrm{NO}_{3}$ radicals and $\mathrm{O}_{3}$. Ph.D. Dissertation, University of Colorado, Boulder, CO, 2018.

5. Pagonis, D.; Price, D. J.; Algrim, L. B.; Day, D. A.; Handschy, A. H.; Stark, H.; Miller, S. L.; de Gouw, J.; Jimenez, J. L.; and Ziemann, P. J. Time resolved measurements of indoor chemical emissions, deposition, and reactions in a university art museum. Environ. Sci. Technol. 2019, 53, 4794-4802.

6. Jokinen, T.; Sipila, M.; Richters, S.; Kerminen, V.-F.; Paasonen, P.; Stratman, F.; Worsnop, D.; Kulmala, M.; Herrmann, H.; and Berndt, T. Rapid autoxidation forms highly oxidized $\mathrm{RO}_{2}$ radicals in the atmosphere. Angew. Comm. 2014, 53, 14596-14600.

7. Seinfeld, J. H and Pandis, S. N. Atmospheric Chemistry and Physics: From Air Pollution to Climate Change. John Wiley \& Sons: Hoboken, NJ, 2006.

8. Azimi, P.; Zhao, D.; and Stephens, B. Estimates of HVAC filtration efficiency for fine and ultrafine particles of outdoor origin. Atmos. Environ. 2014, 98, 337-346.

9. Travers, J.; Marsh, S.; Aldington, S.; Williams, M.; Shirtcliffe, P.; Pritchard, A.; Weatherall, M.; and Beasley, R. Reference ranges for exhaled nitric oxide derived from a random community survey of adults. Am. J. Respir. Crit. Care Med. 2007, 176, 238-242. 